\title{
The effect of different precooling rates and cold storage on milk microbiological quality and composition
}

\author{
Lizandra F. Paludetti, ${ }^{*} †$ Alan L. Kelly,† Bernadette O’Brien, ${ }^{*}$ Kieran Jordan, $\ddagger$ and David Gleeson*1 \\ ${ }^{*}$ Teagasc, Animal and Grassland Research and Innovation Centre, Moorepark, Fermoy, County Cork, Ireland P61 C996 \\ †School of Food and Nutritional Sciences, University College Cork, County Cork, Ireland T12 K8AF \\ ¥Teagasc, Food Research Centre, Moorepark, Fermoy, County Cork, Ireland P61 C996
}

\begin{abstract}
The objective of this study was to measure the effect of different milk cooling rates, before entering the bulk tank, on the microbiological load and composition of the milk, as well as on energy usage. Three milk precooling treatments were applied before milk entered 3 identical bulk milk tanks: no plate cooler (NP), singlestage plate cooler (SP), and double-stage plate cooler (DP). These precooling treatments cooled the milk to $32.0 \pm 1.4^{\circ} \mathrm{C}, 17.0 \pm 2.8^{\circ} \mathrm{C}$, and $6.0 \pm 1.1^{\circ} \mathrm{C}$, respectively. Milk was added to the bulk tank twice daily for $72 \mathrm{~h}$, and the tank refrigeration temperature was set at $3^{\circ} \mathrm{C}$. The blend temperature within each bulk tank was reduced after each milking event as the volume of milk at $3^{\circ} \mathrm{C}$ increased simultaneously. The bacterial counts of the milk volumes precooled at different rates did not differ significantly at $0 \mathrm{~h}$ of storage or at 24 -h intervals thereafter. After $72 \mathrm{~h}$ of storage, the total bacterial count of the NP milk was $3.90 \pm 0.09 \log _{10} \mathrm{cfu} / \mathrm{mL}$, whereas that of the precooled milk volumes were 3.77 $\pm 0.09(\mathrm{SP})$ and $3.71 \pm 0.09(\mathrm{DP}) \log _{10} \mathrm{cfu} / \mathrm{mL}$. The constant storage temperature $\left(3^{\circ} \mathrm{C}\right)$ over $72 \mathrm{~h}$ helped to reduce bacterial growth rates in milk; consequently, milk composition was not affected and minimal, if any, proteolysis occurred. The DP treatment had the highest energy consumption $(17.6 \pm 0.5 \mathrm{Wh} / \mathrm{L})$, followed by the NP $(16.8 \pm 2.7 \mathrm{Wh} / \mathrm{L})$ and $\mathrm{SP}(10.6 \pm 1.3 \mathrm{Wh} / \mathrm{L})$ treatments. This study suggests that bacterial count and composition of milk are minimally affected when milk is stored at $3^{\circ} \mathrm{C}$ for $72 \mathrm{~h}$, regardless of whether the milk is precooled; however, milk entering the tank should have good initial microbiological quality. Considering the numerical differences between bacterial counts, however, the use of the SP or DP precooling systems is recommended to maintain low levels of bacterial counts and reduce energy consumption.
\end{abstract}

Received August 10, 2017.

Accepted November 21, 2017

${ }^{1}$ Corresponding author: David.Gleeson@teagasc.ie
Key words: milk precooling, milk microbiological quality, energy, milk storage

\section{INTRODUCTION}

Milk cooling and refrigerated storage are necessary after milking to reduce bacterial growth rates. Milk leaves the udder at approximately $35^{\circ} \mathrm{C}$, which is a favorable temperature for bacterial growth (Walstra et al., 2006). Thus, the microbial load could increase rapidly if milk is maintained at that temperature. According to Holm et al. (2004), cooling milk rapidly (below $6^{\circ} \mathrm{C}$ ) is necessary to avoid the multiplication of microorganisms, especially psychrotrophs, which can grow at refrigeration temperatures but have optimal and maximal growth temperatures at $>15$ and $20^{\circ} \mathrm{C}$, respectively (Moyer and Morita, 2007). Thus, the precooling of milk (before it enters the bulk tank) could further reduce the bacterial growth rate. A further possible benefit of precooling milk is the reduction of energy costs on-farm (Murphy et al., 2013).

The equipment used to precool milk consists of plate heat exchangers incorporating stainless steel plates in a sandwich arrangement, in which milk and cooling water flow in opposite directions through the spaces between alternate plates (Wang et al., 2007). This system may have 1 or 2 cooling stages, in which well water and well and chilled waters are used in the first and second stages, respectively. O'Connell et al. (2016) observed only a minimal increase in milk bacterial count over time when fresh milk from each milking event was precooled using a single-stage plate cooler before being added to the bulk milk tanks twice daily.

Total bacterial count (TBC) is the main test used by milk processors to assess milk microbiological quality and it quantifies aerobic mesophilic bacteria in milk. In conjunction with TBC, the psychrotrophic bacterial count (PBC) is used to assess the hygiene quality of milk and is an indicator of hygiene conditions on-farm (Harding, 1995; Robinson, 2002). Milk cooling reduces the growth rate of mesophilic and psychrotrophic bacteria, the optimum growth temperatures of which are 
between 20 and $45^{\circ} \mathrm{C}$ and $<7^{\circ} \mathrm{C}$, respectively (Frank and Yousef, 2004; Willey et al., 2008). Thermoduric and thermophilic bacteria are the other relevant groups of bacteria that are measured in milk. These bacteria are important because they can survive thermal treatments such as those frequently applied in dairy processing to reduce bacterial numbers (e.g., pasteurization; Murphy et al., 1999; Robinson, 2002). The main sources of those bacteria are in the cows' environment, because their vegetative cells and spores can be present in feed, forage, bedding material, dust, feces and soil (Scheldeman et al., 2005; Gleeson et al., 2013). Clostridium perfringens and Clostridium botulinum are the pathogenic thermoduric bacteria of most relevance to the dairy industry because of their heat-resistant spores and toxins (Wrigley, 1994; Fernandes, 2009).

Some mesophilic, psychrotrophic, thermoduric, and thermophilic bacterial strains have the ability to produce lipases and proteases. These enzymes hydrolyze fat and protein, resulting in sensorial defects and altering the physico-chemical properties and processability of milk (Chen et al., 2003; Deeth, 2006). Lipolytic activity produces flavors described as rancid and bitter (Deeth, 2006) and could, for example, result in loss of foaming and creaming ability during butter manufacture (Shelley et al., 1987). Celestino et al. (1997) reported that reconstituted UHT milk powder manufactured using 4-d-old raw milk had rancid and bitter flavors compared with UHT milk powder produced using fresh raw milk, probably due to bacterial protease and lipase activity. Therefore, the control of bacterial numbers in milk helps to preserve milk functionality, allowing the production of a range of dairy products in accordance with specific quality parameters.

The aim of this study was to investigate the effect of precooling milk at different rates on the microbiological quality and composition of milk, as well as on energy usage. This study was conducted in a manner that mimicked on-farm milk production conditions: morning and evening milkings, similar milk storage conditions, and use or not of precooling systems.

\section{MATERIALS AND METHODS}

\section{Experimental Design}

This experiment was carried out in the dairy parlor at the Teagasc Animal and Grassland Research and Innovation Centre, Moorepark, Cork, Ireland. Springcalving dairy cows $(\mathrm{n}=210)$ were milked in a 30-unit side-by-side milking parlor, twice daily over two 3 -wk periods, with milking commencing at 0700 and $1430 \mathrm{~h}$. Period 1 extended from June 13 to July 2, 2016, and period 2 extended from July 25 to August 13, 2016.
Before milking, cows' teats were washed and disinfected with chlorhexidine foam teat cleaner (Deosan Teatfoam Advance AG104, Sealed Air, Johnson Diversey Ltd., Dublin, Ireland) and dried using individual paper towels. The milk was transferred from clusters through 16-mm (internal diameter) milk tubes to a mid-level milk line (72 mm, internal diameter), with a milk lift of $1.5 \mathrm{~m}$. The milk was collected in a receiver jar and pumped through a 48-mm stainless steel pipe, using a variable speed milk pump, to the bulk milk tanks (Figure 1). Once the milk flow rate dropped to $0.2 \mathrm{~kg} /$ min, clusters were automatically removed, with a delay time of $20 \mathrm{~s}$. A system to individually wash and disinfect each cluster between each individual cow milking (Cluster Cleanse, Dairymaster, Causeway, Kerry, Ireland) was used. After each milking, the milking equipment was rinsed with water (14 L per milking unit), followed by a hot $\left(75^{\circ} \mathrm{C}\right)$ liquid detergent sterilizer wash (Liquid Gold, Dairymaster) circulated for 8 to $10 \mathrm{~min}$ in the milk line. Following this, the milking equipment was rinsed twice, and the final rinse contained peracetic acid (0.3-0.5\% concentration). An acid-descale (Extrastrong descaler, Dairymaster) was incorporated into the wash regime before the detergent cycle once a week.

The volume of milk collected during each milking was distributed equally into 3 identical bulk milk tanks. The milk line for each bulk tank was fitted with shut-off valves, which were used to control the milk flow rate and guarantee an equal distribution of milk to the tanks. Each bulk tank had capacity of 4,000 L (Swiftcool, Dairymaster) and was fitted with a 5.5-Hp condensing unit. A screen on the front of each tank displayed the milk temperature, time, and milk volume. The milk was cooled to $3^{\circ} \mathrm{C}$ within the tanks and stored for up to $72 \mathrm{~h}$ from once the first milking entered the tank. Approximately 800 and $500 \mathrm{~L}$ of milk were added to each bulk milk tank during the morning and afternoon milkings, respectively. At the end of each 72-h storage period, the milk was collected and the bulk milk tanks were washed using a hot detergent/sterilizer wash $\left(50^{\circ} \mathrm{C}\right)$. This was followed by a cold-water rinse and an additional rinse containing peracetic acid. An acid-descale wash product was used at every third wash.

Before entering the bulk tanks, the milk underwent 1 of 3 precooling treatments: no precooling (NP), singlestage (SP), or double-stage (DP) plate cooling (Figure 1). In the NP treatment, the ground water line was closed; therefore, no precooling was undertaken in that treatment. In the SP treatment (37 plates), the milk exchanged heat with ground water at approximately $15^{\circ} \mathrm{C}$. In the DP treatment (45 plates), the milk was cooled in 2 stages; in the first stage, ground water was used (at approximately $15^{\circ} \mathrm{C}$ ) and in the second stage, 
ice water (at approximately $0^{\circ} \mathrm{C}$ ) was used. Ice water was produced in an ice bank, a system with external melting ice on a coil thermal storage unit with an inline coil array. In the NP, SP, and DP treatments, the milk entered the bulk tanks at average temperatures of $32 \pm 1.4^{\circ} \mathrm{C}, 17 \pm 2.8^{\circ} \mathrm{C}$, and $6 \pm 1.1^{\circ} \mathrm{C}$, respectively. The temperature and volume of milk in each tank was recorded by an integrated system (Swiftcool, Dairymaster) and transmitted via Global System for Mobile communications (GSM) technology to a computer over the two 3 -wk trial periods.

\section{Milk Sampling}

During each milking, a milk sample was collected from the milk line using a sterile Durham flask surrounded by ice to assess the quality of milk entering the tanks. After the initial morning milking, duplicate milk samples $(30 \mathrm{~mL})$ were collected from each bulk tank once the milk temperature within each tank reached $3^{\circ} \mathrm{C}$, corresponding to 0 - $\mathrm{h}$ samples (one milking). The subsequent samples $(24,48$, and $72 \mathrm{~h}$ ) were collected before the addition of each subsequent morning milk on subsequent days, when the bulk tanks contained milk from 2, 4, and 6 milkings, respectively. Before sample collection, the milk was agitated at $24 \mathrm{rpm}$ for $1 \mathrm{~min}$, and samples were collected from the top viewing inlet using sterilized sample dippers. Samples were transported to the laboratory in ice boxes, delivered within 30 min of collection, and analyzed. One sample from each tank was used for microbiological analysis and the other for compositional analysis and SCC.

\section{Microbiological Analysis}

Immediately on delivery to the laboratory, raw milk samples collected every $24 \mathrm{~h}$ were tested in duplicate for a range of bacteria. All the microbiological analyses were performed according to the Standard Methods for the Examination of Dairy Products (Wehr and Frank, 2004). The TBC, PBC, thermoduric (laboratory pasteurization count, LPC), and thermophilic (THERM) bacterial counts were estimated using Petrifilm aerobic count plates, a ready-to-use medium (3M, Technopath, Tipperary, Ireland). Samples tested for LPC were pasteurized at $63^{\circ} \mathrm{C}$ for $30 \mathrm{~min}$, with an additional 5 min that allowed time for the samples to reach the required temperature (Frank and Yousef, 2004); after



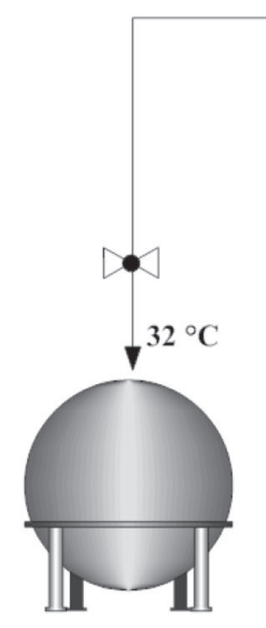

No Plate Cooler

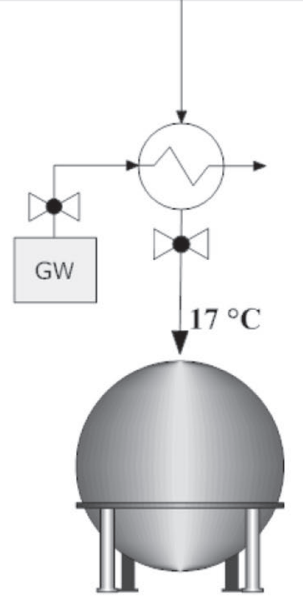

Single Stage Plate Cooler

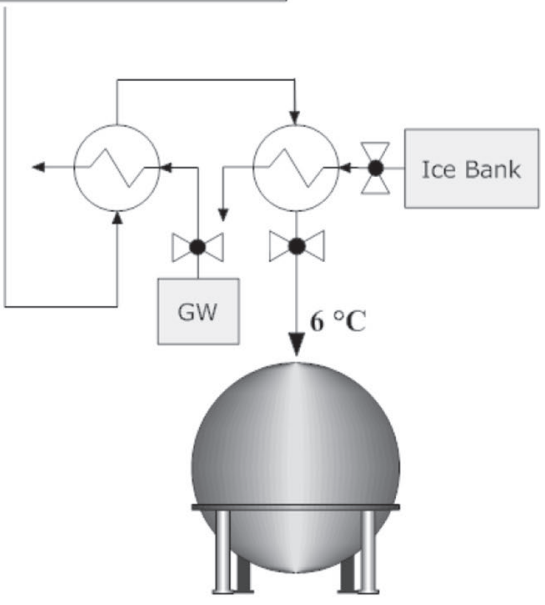

Double Stage Plate Cooler

Storage temperature: $3{ }^{\circ} \mathrm{C}$

Figure 1. Experimental setup using 3 precooling systems: no plate cooler, single-stage plate cooler, and double-stage plate cooler. GW = ground water. 
heating, the samples were cooled to $10^{\circ} \mathrm{C}$ in iced water before testing. Samples tested for TBC and LPC were incubated for $48 \mathrm{~h}$ at $32^{\circ} \mathrm{C}$ (Laird et al., 2004; Pantoja et al., 2009; O'Connell et al., 2016), whereas samples tested for PBC and THERM were incubated at $7 \pm$ $1^{\circ} \mathrm{C}$ for $10 \mathrm{~d}$ and at $55^{\circ} \mathrm{C}$ for $48 \mathrm{~h}$, respectively (Frank and Yousef, 2004). We are aware that using Petrifilm plates at $7^{\circ} \mathrm{C}$ or $55^{\circ} \mathrm{C}$ is outside the validated range. However, a pretrial experiment for THERM indicated that, at the same dilution, plate count agar plates were uncountable due to bacterial colonies spreading over the surface of agar plates, whereas Petrifilm plates were countable (data not shown). In other studies, Petrifilm plates have been used for PBC at $7^{\circ} \mathrm{C}$ (Ramsahoi et al., 2011). The number of bacterial colonies was assessed using a Petrifilm Plate Reader (3M, Technopath). The lipolytic bacterial count (LIP) was performed by spread-plating $100 \mu \mathrm{L}$ of the appropriate dilutions on tributyrin agar with added glyceryl tributyrate (0.01 $\mathrm{mL} / \mathrm{mL}$ of agar prepared; Sigma Aldrich, Dublin, Ireland). The proteolytic bacterial count (PROT) was estimated by spread-plating $100 \mu \mathrm{L}$ of the diluted sample on calcium caseinate agar with added skim milk powder ( $2.5 \mathrm{mg} / \mathrm{mL}$ of agar; Merck, Darmstadt, Germany). For both methods, samples tested were incubated at $37^{\circ} \mathrm{C}$ for $48 \mathrm{~h}$. Lipolytic bacteria colonies were identified as colonies surrounded by a clear zone in a turbid medium, whereas proteolytic bacteria colonies were identified as colonies surrounded by a clear zone in an opaque medium.

The sulfite-reducing Clostridia count (SRC) was assessed by pour-plating $1 \mathrm{~mL}$ of diluted sample in iron sulfite agar and incubating plates under anaerobic conditions for $72 \mathrm{~h}$ at $37^{\circ} \mathrm{C}$, in accordance with ISO standard 15213 (ISO, 2003). Presumptive SRC colonies were identified as black colonies.

\section{Composition and SCC}

Raw milk samples collected every $24 \mathrm{~h}$ had their composition (fat, protein, lactose, and TS contents) and SCC determined using a Fossomatic FC (Foss Electric, Hillerød, Denmark) within $24 \mathrm{~h}$ after arrival in the laboratory.

\section{Peptide Profiles}

Milk samples were collected from the bulk milk tanks at 0 and $72 \mathrm{~h}$ to obtain the peptide profiles. Trichloroacetic acid (TCA) was used to extract the nonprotein fraction of the milk samples, according to the extraction procedure described in IDF method 20-4 (IDF, 2001). The extracts were not diluted but were filtered using $0.45-\mu \mathrm{m}$ syringe cellulose filters (25 $\mathrm{mm}$ diameter,
Chromafil Xtra RC-45/25, Macherey-Nagel, Dublin, Ireland). The HPLC equipment used was an Agilent 1200s system (Agilent Technologies, Santa Clara, CA), with quaternary pump and multi-wavelength detector. A Zorbax 300SB column (4.6 mm internal diameter $\times$ $150 \mathrm{~mm}$; Agilent Technologies) was used to perform the separation of milk peptides. The gradient elution and peak detection methodology was an adaptation of the methodology of Rohm et al. (1996). Samples were injected onto the column $(50 \mu \mathrm{L})$ in duplicate and the flow rate was $0.50 \mathrm{~mL} / \mathrm{min}$.

\section{Assessment of Electricity Consumption}

The energy consumption of each treatment, expressed in Watt-hours (Wh), was measured as the energy usage of each bulk milk tank when each of the precooling treatments was applied. For the DP treatment, the energy usage of the ice bank was also considered. Energy usage was assessed using energy analyzers (EM24 DIN) and Digi Connect wireless WAN cellular routers (Carlo Gavazzi Automation SpA, Lainate, Italy), which measured and transmitted the energy data, respectively. The cumulative energy usage was recorded every $1 \mathrm{~min}$ using the software program Powersoft (Carlo Gavazzi Automation SpA).

\section{Statistical Analysis}

This study was carried out following a Latin square design with repeated measures, in which samples were collected every $24 \mathrm{~h}$, and each bulk tank $(\mathrm{n}=3)$ received a different precooling treatment (NP, SP, DP) in each week $(\mathrm{n}=3)$. Each Latin square was conducted over two 3 -wk periods.

Least squares means for the main effects of period, week, storage time, and precooling system, as well as the interaction between storage time and precooling system, were calculated using the MIXED procedure in SAS 9.3 (SAS Institute Inc., Cary, NC). The fixed effects included in each model were period (1 and 2), week $(1,2$, and 3$)$, precooling system (NP, SP, and DP), and storage time $(0,24,48$, and $72 \mathrm{~h})$. Repeated-measures models were used to account for correlations between time points. Tank within week was considered the experimental unit. The response variables were TBC, PBC, LPC, THERM, PROT, LIP, SRC, SCC, and fat, protein, lactose, and TS contents. Residual checks were made to ensure that the assumptions of the analysis were met. Where appropriate, log-transformation was used to correct distributional issues. The Tukey test (at $5 \%$ error probability) was used to compare the means for all variables. 


\section{RESULTS AND DISCUSSION}

\section{Microbiological Analysis}

During the first milking occasion on the first day of each trial week, a milk sample was collected from the milk line before distribution of the milk to each bulk tank. The average $( \pm \mathrm{SD}) \mathrm{TBC}$ of those milk samples was $3.35 \pm 0.29 \log _{10} \mathrm{cfu} / \mathrm{mL}$, indicating that milk of good microbiological quality was produced. The TBC least squares means of milk samples from each bulk tank collected at $0 \mathrm{~h}$ (after first milking) was $3.54 \pm$ $0.05 \log _{10} \mathrm{cfu} / \mathrm{mL}$. The similarity between the 2 TBC levels for those samples indicated that the precooling treatments did not affect the microbiological load and that milk of good microbiological quality entered each tank. The average $( \pm \mathrm{SD}) \mathrm{TBC}$ of the milk line over $72 \mathrm{~h}$ of storage and the 2 trial periods was $3.55 \pm 0.26$ $\log \mathrm{cfu} / \mathrm{mL}$. Good hygiene practices (e.g., teat preparation, individual cluster cleaning between milkings, and equipment wash routines) contributed to the high quality of the milk entering the bulk milk tanks.

The TBC levels at $0 \mathrm{~h}$ for NP, SP, and DP were $3.55,3.57$, and $3.50 \pm 0.09 \log _{10} \mathrm{cfu} / \mathrm{mL}$, respectively; the $\mathrm{PBC}$ least squares means were $3.11,3.04$, and $3.07 \pm 0.11 \log _{10} \mathrm{cfu} / \mathrm{mL}$; the LIP least squares means were $3.24,3.26$, and $3.28 \pm 0.10 \log _{10} \mathrm{cfu} / \mathrm{mL}$; and the PROT least squares means were $3.20,3.14$, and 3.24 $\pm 0.07 \log _{10} \mathrm{cfu} / \mathrm{mL}$, respectively (Figure 2 ). The differences in the time required to cool the milk to $3{ }^{\circ} \mathrm{C}$ (within the bulk tanks) were expected to affect those initial bacterial counts of the milk volumes; however, the bacterial counts were not significantly different $(P$ $>0.05)$. The NP, SP, and DP treatments precooled the milk to average $( \pm \mathrm{SD})$ temperatures of $32.0 \pm 1.4^{\circ} \mathrm{C}$, $17.0 \pm 2.8^{\circ} \mathrm{C}$, and $6.0 \pm 1.1^{\circ} \mathrm{C}$, respectively; and the average time taken to cool milk to $3^{\circ} \mathrm{C}$ within the bulk milk tanks on the first morning milking on each week was approximately $2 \mathrm{~h}, 1 \mathrm{~h}$, and $20 \mathrm{~min}$, respectively. Given the low initial bacterial counts, the difference in these bulk tank-cooling times was not sufficient to result in different bacterial levels at $0 \mathrm{~h}$.

The different precooling treatments also did not affect any of the bacterial counts over the storage time up to $72 \mathrm{~h}(P>0.05$, Table 1$)$. The volume of milk stored at $3^{\circ} \mathrm{C}$ increased in each bulk tank after each milking, resulting in a decrease in the blend temperature within the tanks over time. After the first 2 milking occasions, the milk volume produced at subsequent milkings blended with a higher volume of milk previously cooled to $3^{\circ} \mathrm{C}$; consequently, the milk was cooled faster than that from the first 2 milking events. Therefore, the maintenance of low temperatures within the bulk tanks did not allow for significant increases in bacterial num-
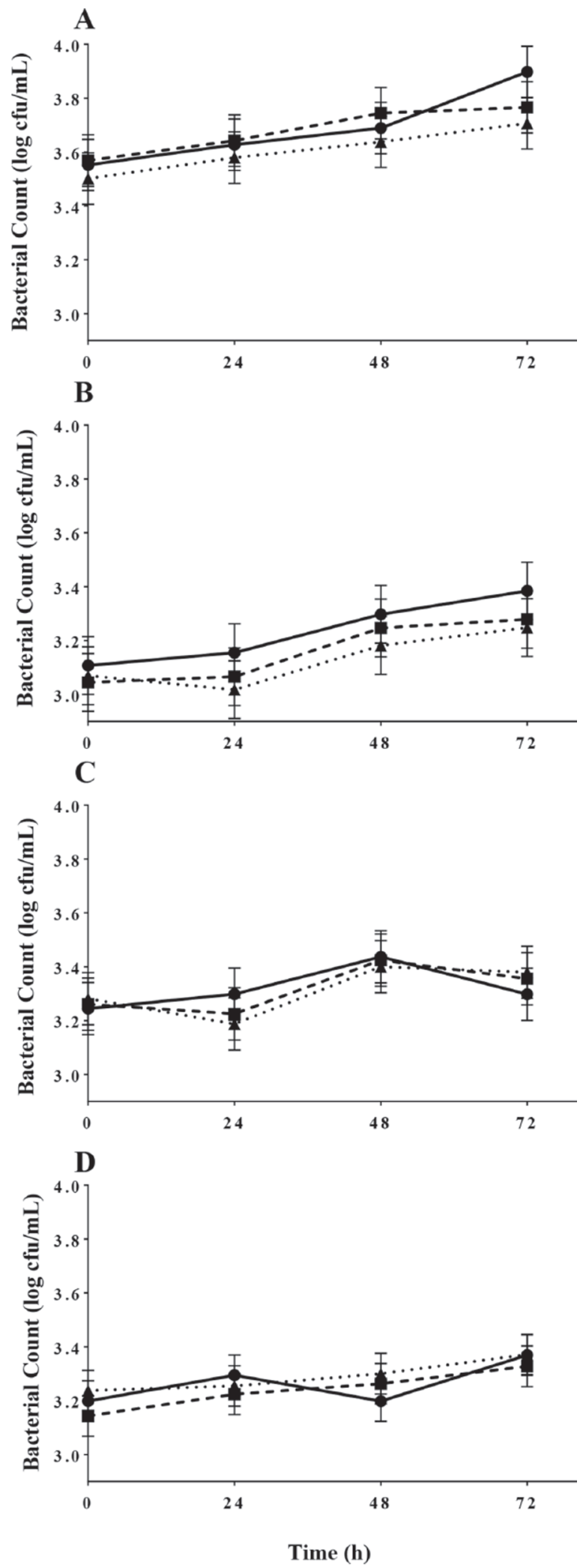

Figure 2. Effect of storage time and different precooling systems ( no plate cooler; $\mathbf{\square}$ single-stage plate cooler; and $\boldsymbol{\Delta}$ double-stage plate cooler) on (A) total, (B) psychrotrophic, (C) lipolytic, and (D) proteolytic bacterial counts $( \pm \mathrm{SD})$ in milk stored for $72 \mathrm{~h}$. 
Table 1. Significance of the main effects of period ( $2 \times 3 \mathrm{wk})$, week ( $6 \mathrm{wk})$, storage time $(72 \mathrm{~h})$, and precooling systems (no plate cooler, single-stage plate cooler, and double-stage plate cooler), as well as the interaction between storage time and precooling system on bacterial counts of milk samples

\begin{tabular}{lccccc}
\hline & \multicolumn{4}{c}{$P$-value } \\
\cline { 2 - 6 } Bacterial count $^{1}$ & Period & Week & $\begin{array}{c}\text { Storage } \\
\text { time }\end{array}$ & $\begin{array}{c}\text { Precooling } \\
\text { system }\end{array}$ & $\begin{array}{c}\text { Precooling system } \\
\times \text { Storage time }\end{array}$ \\
\hline TBC & 0.23 & 0.02 & 0.004 & 0.61 & 0.93 \\
PBC & 0.002 & 0.18 & $<0.001$ & 0.68 & 0.99 \\
LIP & 0.08 & 0.005 & 0.05 & 1.00 & 0.96 \\
PROT & 0.30 & 0.05 & 0.03 & 0.77 & 0.92 \\
LPC & 0.82 & 0.42 & 0.20 & 0.71 & 0.69 \\
THERM & 0.79 & 0.08 & 0.70 & 0.12 & \\
\hline
\end{tabular}

${ }^{1} \mathrm{TBC}=$ total bacterial count, $\mathrm{PBC}=$ psychrotrophic bacterial count, LIP $=$ lipolytic bacterial count, PROT $=$ proteolytic bacterial count, $\mathrm{LPC}=$ thermoduric (laboratory pasteurization) bacterial count, and THERM $=$ thermophilic bacterial count.

bers in the milk; consequently, the precooling system had no significant effect on bacterial counts over time. However, after $72 \mathrm{~h}$, we observed a numerical difference between the bacterial counts in milks subjected to different precooling treatments (Figure 2). After $72 \mathrm{~h}$, $\mathrm{TBC}$ and $\mathrm{PBC}$ (least squares means) in milk that was not precooled were $3.90 \pm 0.09$ and $3.38 \pm 0.11 \log _{10}$ $\mathrm{cfu} / \mathrm{mL}$, respectively. The $\mathrm{SP}$ milk precooled had TBC and PBC (least squares means) of $3.77 \pm 0.09$ and 3.28 $\pm 0.11 \log _{10} \mathrm{cfu} / \mathrm{mL}$, and that precooled using DP had similar TBC and PBC: $3.71 \pm 0.09$ and $3.25 \pm 0.11$ $\log _{10} \mathrm{cfu} / \mathrm{mL}$, respectively.

Storage time affected TBC, PBC, and PROT $(P=$ $0.004, P<0.001$, and $P=0.03$, respectively, Table 1 ), which were $3.54 \pm 0.05,3.07 \pm 0.06$, and $3.19 \pm$ $0.04 \log _{10} \mathrm{cfu} / \mathrm{mL}$ at $0 \mathrm{~h}$; and $3.79 \pm 0.05,3.30 \pm 0.06$, and $3.36 \pm 0.04 \log _{10} \mathrm{cfu} / \mathrm{mL}$ after $72 \mathrm{~h}$, respectively (least squares means across precooling treatments). The increases in $\mathrm{TBC}$ and $\mathrm{PBC}$ were not considered biologically relevant because both were well below the European thresholds determined in document EC no 853/2004 [European Commission, 2004; TBC: 5.00 $\log _{10} \mathrm{cfu} / \mathrm{mL}\left(1.00 \times 10^{5} \mathrm{cfu} / \mathrm{mL}\right) ;$ PBC: $4.22 \log _{10} \mathrm{cfu} /$ $\mathrm{mL}(16,666 \mathrm{cfu} / \mathrm{mL})]$ and typical TBC limits applied by some milk processors [e.g., $4.70 \log _{10} \mathrm{cfu} / \mathrm{mL}(5.00$ $\left.\left.\times 10^{4} \mathrm{cfu} / \mathrm{mL}\right)\right]$. The least squares means of PROT and LIP levels at $72 \mathrm{~h}\left(3.36 \pm 0.04 \log _{10} \mathrm{cfu} / \mathrm{mL}\right.$ and $3.34 \pm 0.06 \log _{10} \mathrm{cfu} / \mathrm{mL}$, respectively) were also not considered relevant as both were well below the limit suggested by Vyletelova et al. [2000; $4.65 \log _{10}$ cfu/ $\mathrm{mL}(44,668 \mathrm{cfu} / \mathrm{mL})$, for each]; those authors suggested that LIP and PROT should be below this level to avoid the production of heat-resistant hydrolytic enzymes when milk is destined for dairy product manufacture, because such enzyme activities could result in loss of milk functional properties and sensory defects.

The PBC was different between the 2 trial periods ( 1 and $2 ; P=0.002$, Table 1 ), whereas TBC and LIP varied between weeks $(P=0.02$ and $P=0.005$, respec- tively, Table 1). Variations in bacterial population in milk at different periods could be related to the cows' health status (e.g., mastitis) or different bacteria strains present in the cows' environment (e.g., feed; Lafarge et al., 2004).

The LPC and THERM counts did not differ between periods and weeks, and storage time and precooling systems did not affect their levels $(P>0.05$, Table 1$)$. At 0 and $72 \mathrm{~h}$, the least squares means of LPC were 0.80 and $0.83 \pm 0.11 \log _{10} \mathrm{cfu} / \mathrm{mL}$, whereas THERM counts were 0.85 and $0.64 \pm 0.13 \log _{10} \mathrm{cfu} / \mathrm{mL}$, respectively. A typical industry LPC specification can range from 2.70 to $3.00 \log _{10} \mathrm{cfu} / \mathrm{mL}$ (500 to $1,000 \mathrm{cfu} / \mathrm{mL}$ ), although there are no European legislation thresholds or dairy processor specifications for thermophilic bacteria in milk. According to Byrne and Bishop (1991), some species of Micrococcus do not grow well on Petrifilm, although those authors concluded that Petrifilm aerobic count plates are a suitable alternative to agar plates for determination of LPC. The SRC levels varied between 0 and $1 \log _{10} \mathrm{cfu} / \mathrm{mL}(10 \mathrm{cfu} / \mathrm{mL})$, indicating a low level of contamination with those organisms. Because of the low incidence, we could not determine the influence of storage and production conditions on these bacteria.

The milk volumes stored in the 3 tanks had low bacterial growth rates, indicating that the storage temperature was effective in preventing an increase in bacterial numbers in the milk over the storage period. O'Connell et al. (2016) stored milk in bulk milk tanks for over $96 \mathrm{~h}$ at 2 or $4^{\circ} \mathrm{C}$ and observed similar results to this study. In that study, milk stored at 2 or $4^{\circ} \mathrm{C}$ for over $72 \mathrm{~h}$ had average TBC, PBC, PROT, and LIP of 3.58, $3.11,2.94$, and $2.91 \log _{10} \mathrm{cfu} / \mathrm{mL}$, respectively. As well as the storage temperature, the initial microbial load of the milk will influence the microbial load over storage (Guinot-Thomas et al., 1995). Therefore, milk entering the tank has to be of high microbiological quality to obtain bacterial counts similar to those obtained after the storage period in the present study. Thus, to minimize 
bacterial growth in milk during storage, it is important that appropriate cleaning practices (for milking equipment and cows) be carried out during milking.

\section{Composition and SCC}

The average $( \pm \mathrm{SD})$ fat, protein, lactose, and TS contents of the sample collected from the milk line after the first milk occasion (first day of each trial week) were $4.52 \pm 0.26,3.58 \pm 0.09,4.76 \pm 0.18$, and 13.36 $\pm 1.93 \%$, respectively. After the first morning milking, the milk samples $(0 \mathrm{~h})$ precooled at different rates had average $( \pm \mathrm{SD})$ fat, protein, lactose, and TS contents similar to those in the milk line sample: $3.49 \pm 0.09$, $3.63 \pm 0.06,4.81 \pm 0.06$, and $12.53 \pm 0.10 \%$ (NP treatment); $3.48 \pm 0.16,3.62 \pm 0.05,4.82 \pm 0.06$, and 12.52 $\pm 0.17 \%$ (SP treatment); and $4.14 \pm 0.22,3.59 \pm 0.07$, $4.76 \pm 0.08$, and $13.12 \pm 0.21 \%$ (DP treatment), respectively. These results, compared with the milk line results, indicate that the precooling treatments did not affect the milk composition as would have been expected. The differences in the fat contents noted could be due to fat distribution when sampling.

The precooling treatments had no effect on milk composition $(P>0.05)$, and storage time did not affect fat, protein, or TS content $(P>0.05)$. After the 2 milking occasions on the first day, the contents of fat, protein, lactose, and TS (least squares means) were 4.41 $\pm 0.06,4.59 \pm 0.08,5.78 \pm 0.05$, and $13.35 \pm 0.07 \%$, and after $72 \mathrm{~h}$ (6 milkings) were $4.44 \pm 0.06,4.58 \pm$ $0.08,5.79 \pm 0.05$, and $13.41 \pm 0.07 \%$, respectively. The protein contents (least squares means) were different in the 2 periods (period 1: $3.55 \pm 0.002 \%$; period 2: 3.63 $\pm 0.002 \%, P=0.0001)$ and between weeks $(P=0.02)$, ranging from 3.54 to $3.72 \%$. The lactose content was also different between periods (period 1: $4.82 \pm 0.002 \%$; period 2: $4.74 \pm 0.002 \%, P=0.007)$. As fresh milk was transferred to the tanks every day, the composition of milk stored within the bulk tanks may have varied according to the content of components in the fresh milk added to the tank on each milking occasion. Those variations in milk composition could be related to cows' physiology or days in milking (Linn, 1988). Also, the interval between milkings can affect milk composition, influencing the TS content of milk collected during the morning and afternoon (Ayadi et al., 2004).

The SCC between periods were statistically different $(P=0.003)$; however, there was a marginal difference of $36.6 \times 10^{3}$ cells $/ \mathrm{mL}$ between periods 1 and 2 , which is probably not biologically relevant. Furthermore, SCC in both periods (period 1: $115.9 \times 10^{3}$ cells $/ \mathrm{mL}$; period 2: $152.5 \times 10^{3}$ cells $\left./ \mathrm{mL}\right)$ were below the European Union legislation threshold $\left(400 \times 10^{3}\right.$ cells $\left./ \mathrm{mL}\right)$.

\section{Peptide Profiles}

High-performance liquid chromatography was performed to determine whether precooling treatments would result in different peptide profiles after $72 \mathrm{~h}$ of storage, thus indicating proteolysis. The chromatograms presented in Figure 3A, B, and C are an average of the chromatograms obtained for all milk samples precooled using the NP, SP, and DP systems, respectively, over the 2 periods. The chromatograms indicated no difference between the initial peptide concentrations in milk volumes precooled at different rates $(0 \mathrm{~h})$, no increase in concentrations over time, and no appearance of peaks that characterize proteolysis. We also noted in those chromatograms the absence of peaks after $20 \mathrm{~min}$, indicating the lack of plasmin action, which hydrolyses $\beta-, \alpha_{\mathrm{S}^{-}}$, and $\alpha_{\mathrm{S}_{2}}$-caseins into peptides and proteose-peptones (Crudden et al., 2005). Therefore, the application of different precooling treatments did not affect proteolysis levels in the milk.

The peptide peak at 15 min (unknown) is the only peptide whose concentration varied over $72 \mathrm{~h}$ and we observed only small differences between treatments for that peak. However, the variation in the concentration of this peptide could be caused by the addition of fresh milk to the tanks, the composition of which could vary, as previously mentioned. The low levels of proteolysis observed might be due to the low levels of proteolytic bacteria in the milk, which did not reach a level sufficient for significant production of proteolytic enzymes (4.65 $\log _{10} \mathrm{cfu} / \mathrm{mL} ;$ Vyletelova et al., 2000). The low storage temperature applied over the storage period could have been effective in reducing the growth rate of proteolytic bacteria and is far from the optimum temperature for most enzymes (Kelly and Fox, 2006).

\section{Energy Consumption}

When the NP and SP treatments were used, the average energy usage $( \pm \mathrm{SD})$ of the bulk tanks was 16.8 \pm 2.7 and $10.6 \pm 1.3 \mathrm{Wh} / \mathrm{L}$ of milk, respectively. The energy usage for the NP treatment was higher than that for the SP treatment because milk entered the bulk tank at a higher temperature $\left(32.0 \pm 1.4^{\circ} \mathrm{C}\right)$ and the compressor running time was longer to achieve the required storage temperature. For the DP treatment, the average energy usage $( \pm \mathrm{SD})$ of the bulk milk tank and ice bank was $4.0 \pm 0.5$ and $13.6 \pm 0.2 \mathrm{Wh} / \mathrm{L}$ of milk, respectively (total energy usage was $17.6 \pm 0.5$ Wh/L of milk).

Considering the similar bacterial counts between the precooling treatments and the energy usage of each treatment over the 72-h storage period, the SP system would achieve low levels of bacterial counts over storage 


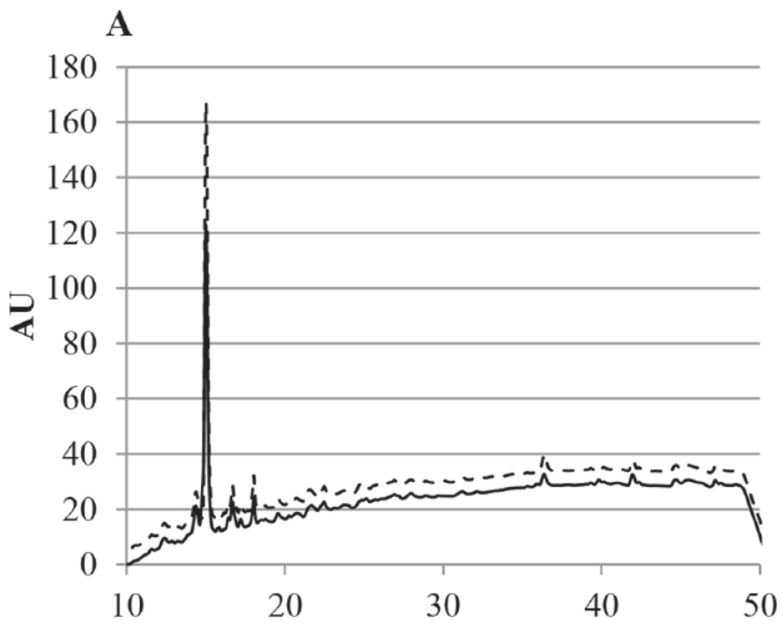

B


Figure 3. Separation of bovine milk peptides by reversed-phase HPLC (measured in absorbance units, AU). Chromatograms of samples precooled using (A) no plate cooler, (B) single-stage plate cooler, and $(\mathrm{C})$ double-stage plate cooler and stored at $3^{\circ} \mathrm{C}$ are shown. Solid line $=0 \mathrm{~h}$; dashed line $=72 \mathrm{~h}$. time and lower energy usage rates compared with the DP treatment. Energy usage was higher for the DP system than for the SP system because of the energy requirements to produce ice. However, this system could be recommended for farms in which an ice bank system is already being used for cooling milk within the bulk tank.

The energy consumption of each treatment is within the ranges reported by Shine et al. (2018), who surveyed 58 Irish commercial dairy farms regarding energy consumption at milking. In that study, the average $( \pm \mathrm{SD})$ energy usages reported were $12.68 \pm 5.20,10.54$ \pm 2.55 , and $14.94 \pm 5.45 \mathrm{Wh} / \mathrm{L}$ for $\mathrm{NP}, \mathrm{SP}$, and $\mathrm{DP}$ systems, respectively. The variation in results between studies could be due to the age of the bulk tanks, the size of the tanks, and how they were installed. The ice bank energy usage in the present study was similar to average usage reported in a survey of 25 Irish commercial dairy farms (13.0 Wh/L; Murphy et al., 2013) and similar to the average value reported by Upton et al. (2013; 19.2 Wh/L, range: 16.0-21.8 Wh/L).

\section{CONCLUSIONS}

The microbiological load of milk precooled at different rates did not differ statistically at $0 \mathrm{~h}$ or over the $72 \mathrm{~h}$ of storage, indicating no significant difference between the precooling treatments. No technologically relevant variations were observed in milk composition, and no considerable enzymatic activity was observed, possibly because of the good microbiological quality of the milk. This study suggests that the bacterial count and composition of milk are minimally affected when milk is stored at $3^{\circ} \mathrm{C}$ for $72 \mathrm{~h}$ whether the milk is precooled or not; however, milk entering the tank should have good initial microbiological quality. Regarding energy usage, the SP treatment required less energy than the other treatments to maintain an equivalent microbiological load in milk. Considering that the milk volumes undergoing the SP and DP treatments had the lowest bacterial counts over $72 \mathrm{~h}$ of storage, it may be beneficial and economical to incorporate the DP system on farms that already use an ice bank bulk milk tank and SP system on other farms. Precooling good quality milk with an SP or DP system and subsequent storage at $3^{\circ} \mathrm{C}$ for $72 \mathrm{~h}$ can maintain good microbiological and compositional quality of milk with reduced energy consumption.

\section{ACKNOWLEDGMENTS}

The authors acknowledge the Teagasc dairy parlor staff involved in this study. The authors also acknowledge the Teagasc laboratory personnel, Jim Flynn and 
Bernard Corrigan, for guidance in the microbiological and composition analysis and HPLC analysis, respectively; as well as the Teagasc research personnel, John Upton and Jim Grant, for their guidance in the energy measurements and statistical analysis, respectively.

\section{REFERENCES}

Ayadi, M., G. Caja, X. Such, M. Rovai, and E. Albanell. 2004. Effect of different milking intervals on the composition of cisternal and alveolar milk in dairy cows. J. Dairy Res. 71:304-310. https://doi org $/ 10.1017 /$ S0022029904000329.

Byrne, R. D., and J. R. Bishop. 1991. Evaluation of a dry medium culture plate (3M Petrifilm AC) for laboratory pasteurized counts. J. Food Prot. 54:308-309.

Celestino, E., M. Iyer, and H. Roginski. 1997. Reconstituted UHTtreated milk: Effects of raw milk, powder quality and storage conditions of UHT milk on its physic-chemical attributes and flavour. Int. Dairy J. 7:129-140.

Chen, L., R. M. Daniel, and T. Coolbear. 2003. Detection and impact of protease and lipase activities in milk and milk powders. Int. Dairy J. 13:255-275. https://doi.org/10.1016/S0958-6946(02)00171-1.

Crudden, A., F. P. Fox, and A. L. Kelly. 2005. Factors affecting the hydrolytic action of plasmin in milk. Int. Dairy J. 15:305-313. https://doi.org/10.1016/j.idairyj.2004.08.008.

Deeth, H. C. 2006. Lipoprotein lipase and lipolysis in milk. Int. Dairy J. $16: 555-562$.

European Commission. 2004. Regulation (EC) No 853/2004 of the European Parliament and of the Council of 29 April 2004 laying down specific hygiene rules for food of animal origin. Off. J. Eur. Union L 226:22-82.

Fernandes, R. 2009. Microbiology Handbook-Dairy Products. 1st ed. Leatherhead Food International Ltd., Epsom, UK.

Frank, J. F., and A. E. Yousef. 2004. Test for groups of microorganisms. Pages 227-248 in Standard Methods for the Examination of Dairy Products. 17th ed. H. M. Wehr and J. F. Frank, ed. American Public Health Association, Washington, DC.

Gleeson, D., A. O'Connell, and K. Jordan. 2013. Review of potential sources and control of thermoduric bacteria in bulk tank milk. Ir. J. Agric. Food Res. 52:217-227.

Guinot-Thomas, P., M. Al Ammoury, and F. Laurent. 1995. Effects of storage conditions on the composition of raw milk. Int. Dairy J. 5:211-223. https://doi.org/10.1016/0958-6946(95)92211-L.

Harding, F. 1995. Milk Quality. 1st ed. Chapman \& Hall, Wiltshire, UK.

Holm, C., L. Jepsen, M. Larsen, and L. Jesperson. 2004. Predominant microflora of downgraded Danish bulk tank milk. J. Dairy Sci. 87:1151-1157. https://doi.org/10.3168/jds.S0022-0302(04)73263 -4 .

IDF. 2001. Milk-Determination of nitrogen content-Part 4: Block digestion method (semi-micro rapid routine method). Standard 20-3. International Dairy Federation (IDF), Brussels, Belgium.

ISO. 2003. ISO 15213: Microbiology of food and animal feeding stuffsHorizontal method for the enumeration of sulphite-reducing bacteria growing under anaerobic conditions. International Organization for Standardization (ISO), Geneva, Switzerland.

Kelly, A. L., and P. F. Fox. 2006. Indigenous enzymes in milk: A synopsis of future research requirements. Int. Dairy J. 16:707-715. https://doi.org/10.1016/j.idairyj.2005.10.018.

Lafarge, V., J. C. Ogier, V. Girard, V. Maladen, J. Y. Leveau, A. Gruss, and A. Delacroix-Buchet. 2004. Raw cow milk bacterial population shifts attributable to refrigeration. Appl. Environ. Microbiol. 70:5644-5650. https://doi.org/10.1128/AEM.70.9.5644 $-5650.2004$

Laird, D. T., S. A. Gambrel-Lenarz, F. M. Scher, T. E. Graham, and R. Reddy. 2004. Microbiological count methods. Pages 153-186 in Standard Methods for the Examination of Dairy Products. 17th ed. H. M. Wehr, J. F. Frank, ed. American Public Health Association, Washington, DC.
Linn, J. G. 1988. Factors affecting the composition of milk from dairy cows. Pages 224-241 in National Research Council (US) Committee on Technological Options to Improve the Nutritional Attributes of Animal Products. Designing Foods: Animal Product Options in the Marketplace. National Academy Press, Washington, DC.

Moyer, C. L., and R. Y. Morita. 2007. Psychrophiles and psychrotrophs. eLS, John Wiley \& Sons, Chichester, UK. https://doi.org/ 10.1002/9780470015902.a0000402.pub2.

Murphy, M. D., J. Upton, and M. O'Mahony. 2013. Rapid milk cooling control with varying water and energy consumption. Biosyst. Eng. 116:15-22. https://doi.org/10.1016/j.biosystemseng.2013.05.007.

Murphy, P. M., D. Lynch, and P. M. Kelly. 1999. Growth of thermophilic spore forming bacilli in milk during the manufacture of low heat powders. Int. J. Dairy Technol. 52:45-50. https://doi.org/10 .1111/j.1471-0307.1999.tb02069.x.

O'Connell, A., P. L. Ruegg, K. Jordan, B. O'Brien, and D. Gleeson. 2016. The effect of storage temperature and duration on the microbial quality of bulk tank milk. J. Dairy Sci. 99:3367-3374. https:// doi.org/10.3168/jds.2015-10495.

Pantoja, J. C. F., D. J. Reinemann, and P. L. Ruegg. 2009. Associations among milk quality indicators in raw milk. J. Dairy Sci. 92:4978-4987. https://doi.org/10.3168/jds.2009-2329.

Ramsahoi, L., A. Gao, M. Fabri, and J. A. Odumeru. 2011. Assessment of the application of an automated electronic milk analyser for the enumeration of total bacteria in raw goat milk. J. Dairy Sci. 94:3279-3287. https://doi.org/10.3168/jds.2010-4102.

Robinson, R. K. 2002. Dairy Microbiology Handbook: The Microbiology of Milk and Milk Products. 3rd ed. John Wiley \& Sons, New York, NY.

Rohm, H., D. Jaros, C. Rockenbauer, M. Riedler-Hellrigl, T. UniackeLowe, and P. F. Fox. 1996. Comparison of ethanol and trichloracetic acid fractionation for measurement of proteolysis in emmental cheese. Int. Dairy J. 6:1069-1077. https://doi.org/10.1016/S0958 -6946(96)00021-0.

Scheldeman, P., A. Pil, L. Herman, P. De Vos, and M. Heyndrickx. 2005. Incidence and diversity of potentially highly heat-resistant spores isolated at dairy farms. Appl. Environ. Microbiol. 71:1480 1494. https://doi.org/10.1128/AEM.71.3.1480-1494.2005.

Shelley, A. W., H. C. Deeth, and I. C. MacRae. 1987. Review of methods of enumeration, detection and isolation of lipolytic microorganisms with special reference to dairy applications. J. Microbiol. Methods 6:123-137. https://doi.org/10.1016/0167-7012(87)90008 $-\mathrm{X}$.

Shine, P., T. Scully, J. Upton, L. Shalloo, and M. D. Murphy. 2018. Electricity and direct water consumption on Irish pasture based dairy farms: A statistical analysis. Appl. Energy. 210:529-537. https://doi.org/10.1016/j.apenergy.2017.07.029.

Upton, J., J. Humphreys, P. W. G. Groot Koerkamp, P. French, P. Dillon, and I. J. M. De Boer. 2013. Energy demand on dairy farms in Ireland. J. Dairy Sci. 96:6489-6498. https://doi.org/10.3168/ jds.2013-6874.

Vyletelova, M., O. Hanus, E. Urbanova, and P. Kopunecz. 2000. The occurrence and identification of psychrotrophic bacteria with proteolytic and lipolytic activity in bulk milk samples at storage in primary production conditions. Czech J. Anim. Sci. 45:373-383.

Walstra, P., J. T. M. Wouters, and T. J. Geurts. 2006. Dairy Technology: Principles of Milk Properties and Processes. 2nd ed. Taylor \& Francis Group, LLC/CRC Press, Boca Raton, FL.

Wang, L., B. Sunden, and R. M. Manglik. 2007. Plate Heat Exchangers: Design, Applications and Performance. 1st ed. WIT Press, Southampton, UK.

Wehr, H. M., and J. F. Frank. 2004. Standard Methods for the Examination of Dairy Products. 17th ed. American Public Health Association, Washington, DC.

Willey, J. M., L. M. Sherwood, and C. J. Woolverton. 2008. Prescott, Harley, and Klein's Microbiology. 7th ed. McGraw-Hill Higher Education, New York, NY.

Wrigley, D. M. 1994. Clostridium perfringens. Pages 133-167 in Foodborne Disease Handbook. Volume I: Diseases Caused by Bacteria. Y. H. Hui, J. R. Gorham, K. D. Murrell, D. O. Cliver, ed. Marcel Dekker, New York, NY. 